\title{
Perhitungan Nilai Digital Radiansi Berdasarkan Band Pada Citra Alos Avnir-2 Di Wilayah Sidangoli Dehe Kecamatan Jailolo Selatan Kabupaten Halmahera Barat
}

\author{
Rustam E. Pembonan ${ }^{1}$, Muh. Ansar Amran ${ }^{2}$ dan Firdaut Ismail ${ }^{1}$ \\ ${ }^{1}$ Program Studi Ilmu Kelautan, FPIK. Universitas Khairun, Ternate \\ ${ }^{2}$ Jurusan Ilmu kelautan, FIKP, Universitas Hasanuddin, Makassar
}

\begin{abstract}
ABSTRAK
Citra satelit yang digunakan dalam penelitian ini adalah Citra ALOS AVNIR-2 dengan resolusi spasial $10 \mathrm{~m}$ dan terdiri atas empat band yang terdiri atas tiga band merupakan spektral visible (cahaya tampak) dan satu gelombang merupakan spektral infrah merah. Cakupan area dari citra ALOS AVNIR-2 yang digunakan dalam penelitian ini adalah wilayah Sidangoli Dehe Kecamatan Jailolo Selatan Kabupaten Halmahera Barat. Adapu tujuan dari penelitian ini adalah menentukan nilai digital radiansi pada citra ALOS AVNIR-2 di Wilayah Sidangoli Dehe. Metode yang digunakan dalam penelitian ini merupakan aplikasi algoritma dalam pengolahan dan analisis citra. Sebelum melakukan koreksi radiansi citra maka harus dilakukan pengolahan awal terhadap citra yang meliputi koreksi atmosferik, koreksi geometric, dan komposit citra. Hasil dari penelitian ini merupakan citra radiansi yang telah dikoreksi secara matematis dengan model algoritma melalui transformasi dari Nilai Digital (DN) yang merupakan bilangan berbasis $2^{8}$. Nilai digital citra radiansi tersebut terintegrasi secara langsung dengan histogram sehingga dapat divisualisasikan melalui julat gelombang spektral. Citra dari hasil penelitian ini diketahui bahwa nilai digital radiansi masingmasing band dari Citra ALOS AVNIR-2 yaitu band 1 dengan nilai $0-110 \mathrm{wm}^{-2} \mathrm{sr}^{-1} \mu \mathrm{m}^{-1}$, band 2 dengan nilai $0-121 \mathrm{wm}^{-2} \mathrm{sr}^{-1} \mu \mathrm{m}^{-1}$, band 3 dengan nilai $0-111 \mathrm{wm}^{-2} \mathrm{sr}^{-1} \mu \mathrm{m}^{-1}$, dan band 4 dengan nilai $0-170 \mathrm{wm}^{-2} \mathrm{sr}^{-1} \mu \mathrm{m}^{-1}$.
\end{abstract}

Kata kunci : Citra ALOS AVNIR-2, Nilai Digital, Radiansi, Histogram, Sidangoli Dehe

\begin{abstract}
The satellite image used in this study is the ALOS AVNIR-2 image with a spatial resolution of $10 \mathrm{~m}$ and consists of four bands consisting of three bands which are spectral visible and one wave is red spectral. The coverage area of the ALOS AVNIR-2 image used in this study is the Sidangoli Dehe area, South Jailolo District, West Halmahera Regency. The objective of this study was to determine the digital radianship value in the image of ALOS AVNIR-2 in the Sidangoli Region Dehe. The method used in this study is the application of algorithms in image processing and analysis. Before correcting image radiance, the initial processing of the image must include atmospheric correction, geometric correction, and image composite. The results of this study are radiance images that have been mathematically corrected with an algorithm model through the transformation of Digital Values $(D N)$ which are 28 based numbers. The digital values of these radians are directly integrated with histograms so that they can be visualized through spectral wave ranges. The image from the results of this study shows that the digital values of each band radians of the ALOS AVNIR-2 image are band 1 with values $0-110 \mathrm{wm}-2 \mathrm{sr}-1 \mu \mathrm{m}-1$, band 2 with values $0-121 \mathrm{wm}-2 \mathrm{sr}-1 \mu \mathrm{m}-1$, band 3 with values 0 - $111 \mathrm{wm}-2 \mathrm{sr}-1 \mu \mathrm{m}-1$, and band 4 with values 0 - $170 \mathrm{wm}-2 \mathrm{sr}-1 \mu \mathrm{m}-1$.
\end{abstract}

Keywords: ALOS AVNIR-2 image, Digital Value, Radiation, Histogram, Sidangoli Dehe 


\section{Pendahuluan}

Penginderaan jauh merupakan suatu cara untuk mendapatkan atau mengumpulkan informasi mengenai obyek dengan dasar pengukuran dilakukan pada jarak tertentu dari objek atau kejadian tersebut tanpa menyentuh atau melakukan kontak fisik langsung dengan objek yang sedang diamati. Informasi yang diperoleh berupa radiasi gelombang elektromagnetik yang datang dari suatu obyek di permukaan bumi, baik yang dipancarkan maupun yang dipantulkan oleh obyek tersebut yang kemudian diterima oleh sensor. Sensor ini dapat berupa kamera atau peralatan elektronik lainnya (Butler et al. 1998).

Pemanfaatan penginderaan jauh telah berkembang dengan pesat seiring dengan kemajuan teknologi. Menurut Sutanto (1986) alasan yang mendasari peningkatan pemanfaatan penginderaan jauh salah satunya adalah citra menggambarkan obyek, daerah gejala permukaan bumi dengan (1) wujud dan letak obyek yang sama dengan permukaan bumi, (2) relatif lengkap, (3) meliputi daerah yang luas dan (4) permanen. Wujud yang lengkap ini memungkinkan penggunaannya untuk berbagai bidang, baik secara sendirisendiri maupun secara bersama-sama. Karena itu citra dapat digunakan untuk kajian berbagai bidang seperti hidrologi, oseanografi, geografi, biologi, kehutanan dan pertanian. Jadi citra dapat digunakan untuk inventarisasi sumber daya alam. Menurut Sutanto (1986), tiap obyek memiliki karakteristik tersendiri di dalam menyerap dan memantulkan tenaga yang diterima olehnya. Melalui pantulan spektral obyek dapat dikenali dan dibedakan secara lebih baik dengan obyek lain. Ciri pengenalan obyek menurut Lilesand dan Kiefer (1979) disebut dengan unsur interpretasi citra. Ciri pengenalan meliputi ciri spektral, ciri spasial dan ciri temporal. Diantara tiga ciri ini ciri spektral merupakan ciri utama, artinya ciri lain bisa tampak setelah mengenali ciri spectral.

Salah satu langkah yang paling penting dalam proses pengolahan data citra adalah menganalisis nilai radiansi sutu objek pada citra sebelum melakukan analisis nilai reflektansi. Nilai radiansi pada citra merupakan jumlah fluks energi per satuan luas, pada panjang gelombang tertentu. Nilai radiansi pada citra sangat tergantung pada jenis citra dan kondisi resolusi citra. Sidangoli Dehe merupakan wilayah pesisir dan terdiri atas beberapa pulaupulau kecil. Berdasarkan hasil observasi diketahui di wilayah ini mengalami perubahan tutupan lahan yang relatif cepat karena adanya konversi lahan. Oleh sebab itu, interpretasi objek di wilayah ini melalui aplikasi penginderaan jauh merupakan pilihan yang tepat dalam melakukan monitoring perubahan tutupan lahan.

\section{Metode Penelitian}

\subsection{Lokasi dan Waktu Penelitian}

Lokasi penelitian meliputi wilayah Sidangoli Dehe Kecamatan Jailolo Selatan Kabupaten Halmahera Barat sedangkan pengolahan dan analisis citra dilakukan di Laboratorium Penginderaan Jauh Jurusan Ilmu Kelautan Universitas Hasanuddin Makassar. Adapun waktu penelitian dilaksanakan selama 9 bulan yaitu Maret hingga November 2013

\subsection{Alat dan Bahan}

Bahan yang akan digunakan dalam penelitian ini adalah citra ALOS AVNIR-2. Sedangkan alat-alat utama yang akan digunakan adalah :

1. GPS-receiver dan Kamera digital

2. Software Penginderaan Jauh

3. Komputer pengolah data 


\subsection{Metode Penelitian}

Penelitian dilakukan sesuai dengan alur penelitian yang disajikan. Berdasarkan alur penelitian maka penelitian ini akan dilaksanakan dalam beberapa tahap :

\subsubsection{Pengolahan awal citra ALOS AVNIR-2}

Pengolahan awal citra ALOS AVNIR-2 dalam penelitian ini meliputi koreksi atmosferik, koreksi radiometrik dan dan pembuatan komposit data citra. Adapun proses-proses dari pengelohan awal citra ALOS AVNIR-2 sebagai berikut :

\section{Koreksi atmosferik}

Koreksi atmosferik yang dilakukan pada penelitian ini akan menggunakan metode dark subtract. Nilai-nilai pixel pada band-4 akan diplot terhadap band-band lainnya, kemudian ditentukan garis regresi linier antar kedua band. Nilai offset $\alpha$ pada sumbu x merupakan nilai estimasi path radiance yang akan dijadikan pengurang terhadap nilai-nilai pixel pada band yang bersangkutan (Mather, 2004).

\section{Koreksi Geometrik}

Koreksi geometrik merupakan proses perujukan titik-titik pada citra ke titik-titik yang sama di lapangan ataupun di peta, yang diketahui persis koordinatnya. Pasangan titik-titik tersebut kemudian digunakan untuk membangun fungsi matematik yang menyatakan hubungan antara posisi sembarang titik pada citra dengan titik obyek yang sama di lapangan.

Koreksi geometrik pada penelitian ini dilakukan dengan menggunakan metode transformasi koordinat polinomial orde satu. Penyesuaian proyeksi dilakukan sesuai dengan sistem proyeksi UTM, dengan menggunakan titik kontrol medan (GCP) yang koordinatnya ditentukan dari lapangan melalui pengukuran dengan GPS. Transformasi koordinat orde satu mensyaratkan jumlah titik kontrol GCP sekurang-kurangnya 3 titik. Semakin banyak titik kontrol yang digunakan akan memberikan hasil yang lebih baik apabila titik-titik kontrol tersebut tersebar merata pada citra.

Proses selanjutnya adalah interpolasi nilai spektral bagi masing-masing pixel. Interpolasi nilai pixel yang digunakan dalam penelitian ini adalah proses resampling tetangga terdekat (nearest neighbour resampling). Proses ini dipilih karena tidak merubah nilai pixel yang bersangkutan, melainkan hanya mengambil kembali nilai dari pixel terdekat yang telah tergeser ke posisi yang baru.

\section{Pembuatan Citra Komposit}

Citra komposit warna merupakan paduan citra dari tiga saluran yang berbeda. Penyusunan citra komposit warna dimaksudkan untuk memperoleh gambaran visual yang lebih baik sehingga pengenalan obyek dan pemilihan sampel dapat dilakukan. Citra komposit warna yang dibuat dalam penelitian ini adalah citra komposit dengan kombinasi RGB321. Citra komposit ini akan menampilkan obyek sebagaimana warna aslinya.

\subsubsection{Survei lapangan Dan Identifikasi Objek Tutupan Lahan}

Kedalaman perairan diukur dengan menggunakan fathometer. Koordinat titik pengukuran diukur dengan menggunakan GPS. Bersamaan dengan pengukuran kedalaman perairan, dilakukan pula pengukuran pasang surut yang datanya akan digunakan untuk mengoreksi hasil pengukuran kedalaman perairan. 


\subsubsection{Konversi nilai digital (DN) citra ALOS AVNIR-2 ke nilai radiansi}

Kalibrasi radiansi citra ALOS AVNIR-2 dilakukan dengan menggunakan absolut calibration coefficient dan offset yang tercantum dalam Ancillary Record pada file metadata citra (leader file). Konversi nilai digital (DN) ke nilai radiansi, untuk masing-masing pixel pada band-i, dilakukan dengan menggunakan rumusan :

$$
L_{\text {band-i }}=\left(\text { absCalCoef } f_{\text {band-i }} \cdot D N\right)+\text { offset }_{\text {band }-i} \quad \mathrm{Wm}^{-2} \mathrm{sr}^{-1} \mu \mathrm{m}^{-1}
$$

dimana :

$L_{\text {band-i }}$ : nilai radiansi pixel pada band-i

absCalCoef dan offset : faktor kalibrasi radiometrik, $\left(\mathrm{Wm}^{-2} \mathrm{sr}^{-1} \mu \mathrm{m}^{-1}\right)$

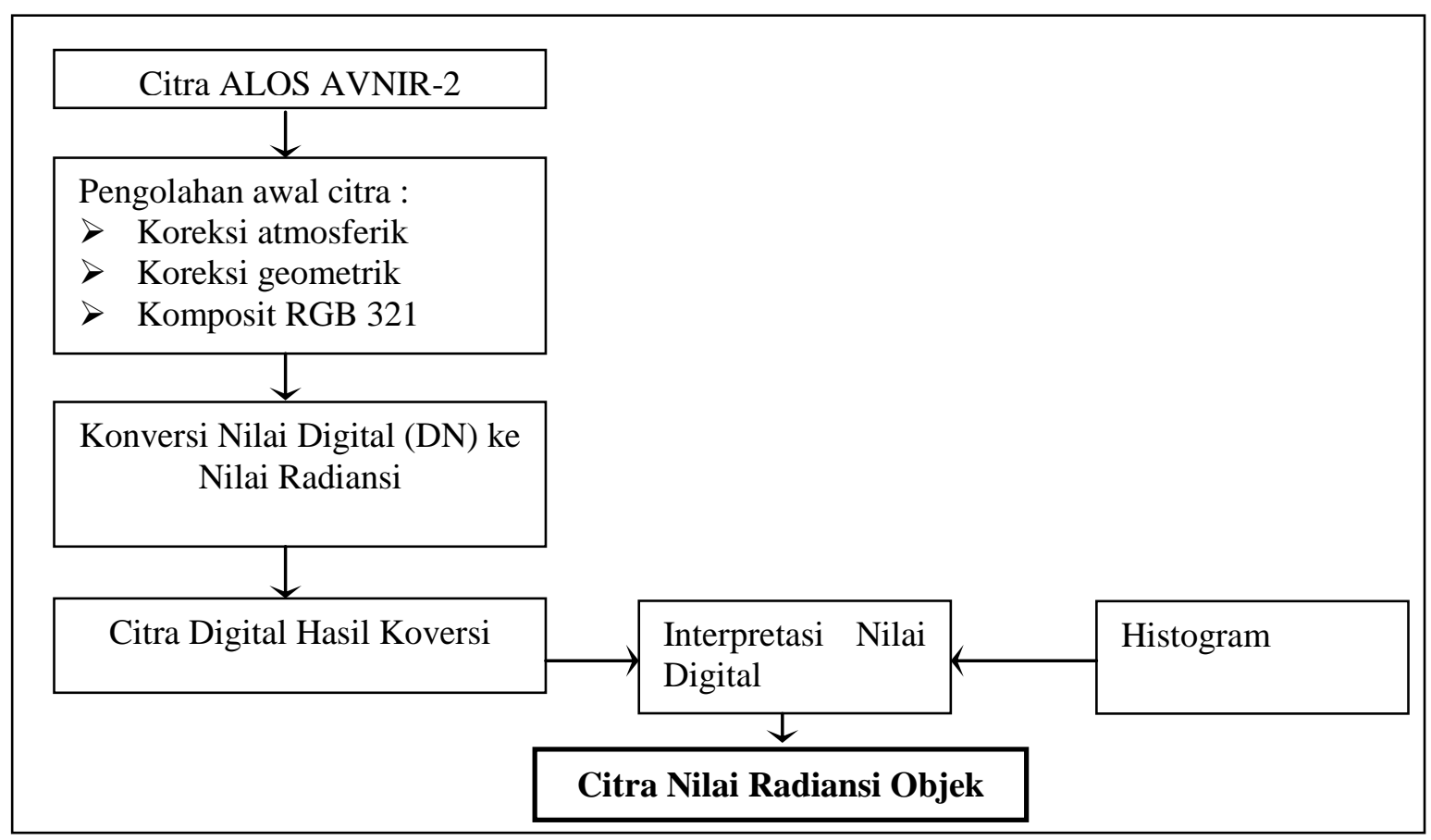

Gambar 1. Alur Penelitian

\section{Hasil dan Pembahasan}

\subsection{Gambaran Lokasi Penelitian}

Desa Sidangoli Dehe merupakan salah satu desa pesisir dengan luas wilayah daratan 861,6 Ha. Secara administratif, desa ini terletak dalam wilayah Kecamatan Jailolo Selatan, Kabupaten Halmahera Barat Propinsi Maluku Utara (Data Monografi Desa Sidangoli Dehe tahun 2013). Desa Sidangoli Dehe memiliki batas-batas desa sebagai berikut, sebelah utara berbatasan dengan Desa Domato, sebelah timur berbatasan dengan Desa Ake Jailolo, sebelah barat berbatasan dengan Desa Sidangoli Gam, sebelah selatan berbatasan dengan laut, merupakan perairan laut yang relatif masih dipengaruhi secara langsung oleh Laut Maluku. Secara geografis, Desa Sidangoli Dehe terletak di wilayah perairan laut yang mendapat pengaruh secara langsung dari Laut Maluku. Adapun posisi geografis batas penelitian meliputi $0^{\circ} 50^{\prime} 29.28^{\prime \prime} \mathrm{LU}-0^{\circ} 53^{\prime} 42.92 \mathrm{LU}$ dan $127^{\circ} 31^{\prime} 39.94^{\prime \prime} \mathrm{BT}-127^{\circ} 28^{\prime} 27.09 \mathrm{BT}$. 


\section{2 . Pengolahan dan Hasil Analisis Citra}

\subsubsection{Gambaran Citra ALOS AVNIR-2}

Citra ALOS (Advanced Land Observing Satellite) merupakan citra dari satelit penginderaan jauh yang dikembangkan oleh Jepang. Citra ALOS AVNIR-2 yang dipakai dalam penelitian ini adalah ALOS_ALAV2A239373580 yang terdiri atas dua bagian kompoten yaitu fie meta data dan file citra. File meta data sebagai file pendukung merupakan file yang menjelaskan tentang identitas citra tersimpan dalam format Text Documents (. *txt).

Tabel 1. Spesifikasi ALOS AVNIR-2. Sumber: JAXA, 2008

\begin{tabular}{|c|c|c|l|}
\hline Band & $\begin{array}{c}\text { Panjang } \\
\text { Gelombang }(\mu \mathrm{m})\end{array}$ & $\begin{array}{c}\text { Resolusi } \\
\text { Spasial (meter) }\end{array}$ & \multicolumn{1}{c|}{ Fungsi } \\
\hline 1 & $0,45-0,52$ & 10 & $\begin{array}{l}\text { Penetrasi tubuh air, analisis } \\
\text { penggunaan lahan, tanah, dan } \\
\text { vegetasi. Pembedaan vegetasi dan } \\
\text { lahan. }\end{array}$ \\
\hline 2 & $0,52-0,60$ & 10 & $\begin{array}{l}\text { Pengamatan puncak pantulan } \\
\text { vegetasi pada saluran hijau yang } \\
\text { terletak di antara dua saluran } \\
\text { penyerapan. Pengamatan ini } \\
\text { dimaksudkan untuk membedakan } \\
\text { tanaman sehat terhadap tanaman } \\
\text { yang tidak sehat }\end{array}$ \\
\hline 3 & $0,63-0,69$ & 10 & $\begin{array}{l}\text { Saluran terpenting untuk } \\
\text { membedakan jenis vegetasi. Saluran } \\
\text { ini terletak pada salah satu daerah } \\
\text { penyerapan klorofil dan } \\
\text { memudahkan pembedaan antara } \\
\text { lahan terbuka terhadap lahan } \\
\text { bervegetasi }\end{array}$ \\
\hline 4 & $0,63-0,69$ & $\begin{array}{l}\text { Saluran yang peka terhadap biomasa } \\
\text { vegetasi. Juga untuk identifikasi } \\
\text { jenis tanaman, memudahkan } \\
\text { pembedaan tanah dan tanaman. }\end{array}$ \\
\hline
\end{tabular}

File yang paling utama adalah yang citra yang merupakan file data raster (pixel) yang tersimpan dalam format * tif dengan resolusi spasial $10 \mathrm{~m}$. Jenis file raster tersebut terdiri atas empat band (penjang gelombang tertentu dengan setiap band mempunyai spesifikasi tertentu. Berdasarkan penjang gelombang, B1 $(0,45-0,52 \mu \mathrm{m}), \mathrm{B} 2(0,52-0,60 \mu \mathrm{m}), \mathrm{B} 3$ $(0,63-0,69 \mu \mathrm{m})$ dan B4 $(0,76-0,90 \mu \mathrm{m})$ Adapun gambaran dan spesifikasi setiap band tentang citra ALOS AVNIR-2 yang dipakai dalam penelitian ini dapat dilihat dalam viualisasi greyscale pada Tabal 1.

\subsubsection{Pengolahan Awal Citra}

Pengolahan awal citra dalam penelitian ini dibedakan atas yang meliputi : (a) Koreksi atmosferik, (b) Koreksi geometrik, (c) Komposit RGB, dan (d) land-masking. Adapun hasil dari proses pengolahan awal citra dijelaskan sebagai berikut : 


\section{a. Koreksi atmosferik}

Langkah pertama yang dilakukan dalam melakukan koreksi atmosferik adalah menentukan batas area wilayah penelitian. Koreksi atmosferik dapat dilakukan dengan dua cara yaitu membuat persamaan regresi dan mencari nilai digital (DN) sebagai nilai pengoreksi (Dark Substrat). Koreksi atmosferik dengan persamaan regresi dilakukan secara berpasangan antara band 4 terhadap band 1, band 2 dan band 3. Hasil dari persamaan regresi selanjutnya dilakukan koreksi secara matematis melalui formulasi algoritma terhadap masing-masing band yang dikoreksi. Adapun metode koreksi atmosferik Dark Substrat yaitu menentukan nilai digital dengan cara melakukan kalkulasi statistic terhadap citra yang ditampilkan secara histogram dan terintegrasi dengan nilai-nilai digital citra.

Hasil koreksi atmosferik, histogram dan nilai-nilai digital citra sebelum dilakukan koreksi atmosferik ditemukan nilai offset pada sumbu x sedangkan pada citra yang telah terkoreksi atmosferik nilai tersebut sudah tidak ada (nilai 0). Secara matematis, melakukan koreksi atmosferik dibuat dengan melakukan pengurangan berdasarkan nilai offset pada sumbu $\mathrm{x}$ terhadap semua nilai digital yang terdapat pada band citra. Adapun hasil koreksi atmosferik terhadap masing-masing band dari citra ALOS AVNIR-2 yang digunakan dalam penelitian ini terdapat pada Tabel 2 :

Tabel 2. Nilai Digital setiap Band yang Terkoreksi Atmosferik

\begin{tabular}{|c|c|c|c|}
\hline Band & $\begin{array}{c}\text { Panjang Gelombang } \\
(\mu \mathrm{m})\end{array}$ & $\begin{array}{c}\text { Nilai Offset setiap } \\
\text { Band }\end{array}$ & $\begin{array}{c}\text { Nilai Digital setiap Band } \\
\text { setelah Terkoreksi }\end{array}$ \\
\hline 1 & Band 1:0.42-0.50 & 70 & 177 \\
\hline 2 & Band 2:0.52-0.60 & 37 & 218 \\
\hline 3 & Band 3:0.61-0.69 & 19 & 236 \\
\hline 4 & Band 4:0.76-0.89 & - & 249 \\
\hline
\end{tabular}

\section{b. Koreksi geometrik}

Citra yang digunakan pada penelitian ini merupakan citra yang telah di koreksi geometrik terlebih dahulu sesuai dengan system koordinat bumi, agar semua informasi data citra sesuai keberadaannya di bumi (real word). Koreksi geometrik dalam penelitian ini menggunakan referensi proyeksi Universal Transverse Mercator (UTM) datum WGS84 dan Zone $52 \mathrm{~N}$. Ada dua istilah dalam koreksi geometrik, yaitu registrasi dan rektifikasi. Registrasi adalah proses koreksi geometrik dari citra belum terkoreksi dengan citra yang sudah terkoreksi. Rektifikasi adalah proses koreksi geometrik antara citra belum terkoreksi dengan peta. Dalam penelitian ini. Proses rektifikasi dilakukan terhadap citra ALOS AVNIR2 dengan menggunakan peta Rupa Bumi Indonesia (RBI) 1:50.000. data dari hasil survey lapangan yang diperoleh melalui GPS (Global Positioning System). Adapun hasil koreksi geometric dalam penelitian ini terdapat pada Tabel 3 .

Tabel 3. Koreksi Geometrik

\begin{tabular}{|c|c|c|c|c|c|l|}
\hline \multirow{2}{*}{ No } & \multicolumn{2}{|c|}{$\begin{array}{c}\text { Koordinat belum } \\
\text { Terkoreksi }\end{array}$} & \multicolumn{2}{|c|}{ Koordinat Hasil Koreksi } & \multirow{2}{*}{ RMS } & $\begin{array}{l}\text { Keterangan Titik } \\
\text { Referensi }\end{array}$ \\
\cline { 2 - 5 } & $\mathrm{X}$ & $\mathrm{Y}$ & $\mathrm{X}$ & $\mathrm{Y}$ & & $\begin{array}{l}\text { Persimpangan } \\
\text { Jalan }\end{array}$ \\
\hline 1 & 6829.88 & 6601.13 & 344685,70 & $83.594,50$ & 0.04 \\
\hline 2 & 4435.0 & 5860,25 & $320.753,43$ & 90.985 .95 & 0,34 & Belokan Jalan \\
\hline 3 & 5736,0 & 5131,76 & $333.780,24$ & $98.272,72$ & 0,69 & Persimpangan \\
\hline
\end{tabular}




\begin{tabular}{|c|c|c|c|c|c|l|}
\hline & & & & & & Jalan \\
\hline 3 & 7043,93 & 4110,17 & $346.860,17$ & $108.482,08$ & 0,31 & $\begin{array}{l}\text { Persimpangan } \\
\text { Jalan }\end{array}$ \\
\hline
\end{tabular}

\section{c. Komposit RGB 321}

Pembuatan citra komposit dilakukan untuk memperoleh gambaran tentang jenis-jenis objek yang terdapat pada citra. Proses ini dilakukan dengan tujuan untuk memudahkan visualisasi dalam interpretasi pengenalan objek dan memudahkan dalam membuat klasifikasi objek pada citra. Proses komposit RGB dilakukan dengan membuat kombinasi warna dasar yang berbeda yaitu Merah (Red), Hijau (Green) dan Biru (Blue) yang terdapat pada pada tiga jenis saluran band pada citra tersebut. Penelitian ini menggunakan Komposit RGB 321 karena dapat menembus daerah dangkal yang efektif sampai sampai pada kedalaman tertentu. Komposit RGB 321 dari citra ALOS AVNIR-2 sesuai dengan lokasi penelitian (Sidangoli Dehe) terdapat pada Gambar 2 (b).
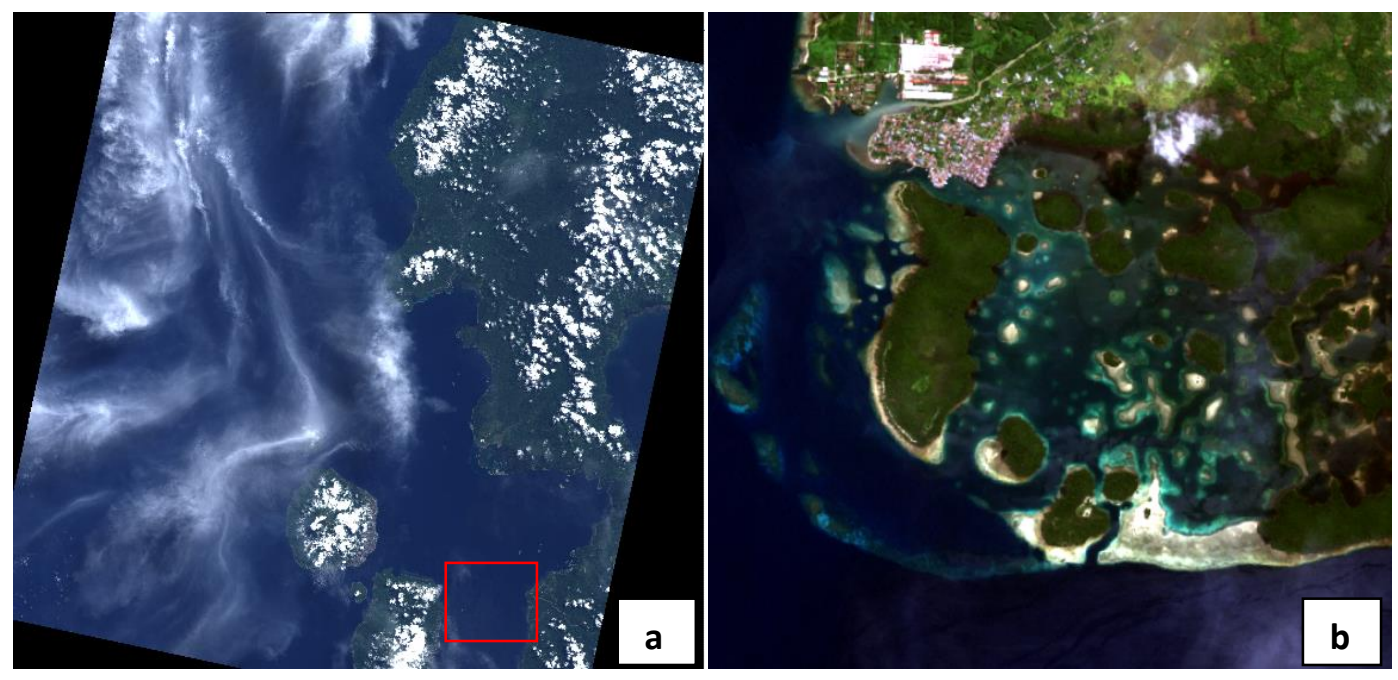

Gambar 2. Hasil Komposit RGB 321, (a) RGB 321 Liputan Scene Citra yang digunakan, (b) RGB 321 Area Sidangoli Dehe

\subsection{Konversi Nilai Digital (DN) ke Nilai Radiansi dan Nilai Reflektansi}

Konversi nilai digital menjadi nilai radiansi dilakukan atas dua tahap yaitu menentukan radiansi spektral dan menentukan reflektansi spektral. Radiansi spectral adalah jumlah fluks energi per satuan luas, pada panjang gelombang tertentu. Penentuan nilai radiansi spectral untuk masing-masing pixel pada band-i, dilakukan dengan menggunakan rumusan pada persamaan 1. Berdasarkan rumus tersebut selanjutnya dibuat persamaan matematis masing-masing band sesuai dengan variabel yang terdapat pada Tabel 5 .

Tabel 5. Radiansi Spektral Citra ALOS AVNIR-2

\begin{tabular}{|l|l|l|l|}
\hline No & $\begin{array}{l}\text { Band } \\
(\mu \mathrm{m})\end{array}$ & $\begin{array}{l}\text { absCalCoef } \\
\left(\mathrm{Wm}^{-2} \mathrm{sr}^{-1} \mu \mathrm{m}^{-1}\right)\end{array}$ & Offset \\
\hline 1 & $0.42-0.50$ & 0,5946 & 0,03 \\
\hline 2 & $0.52-0.60$ & 0,5541 & 0,02 \\
\hline 3 & $0.61-0.69$ & 0,4730 & 0,02 \\
\hline 4 & $0.76-0.89$ & 0,6689 & 0,00 \\
\hline
\end{tabular}


Tahapan selanjutnya dalam mengkonversi nilai digital ke nilai radiansi spectral adalah mentransformasi persamaan matematis menjadi model algoritma yang dibuat berdasarkan persamaan matematis dari Tabel 4. Adapun citra hasil konversi DN menjadi citra radiansi spectral dapat diketahui berdasarkan histogram citra masing-masing band yang tedapat pada Gambar 3.
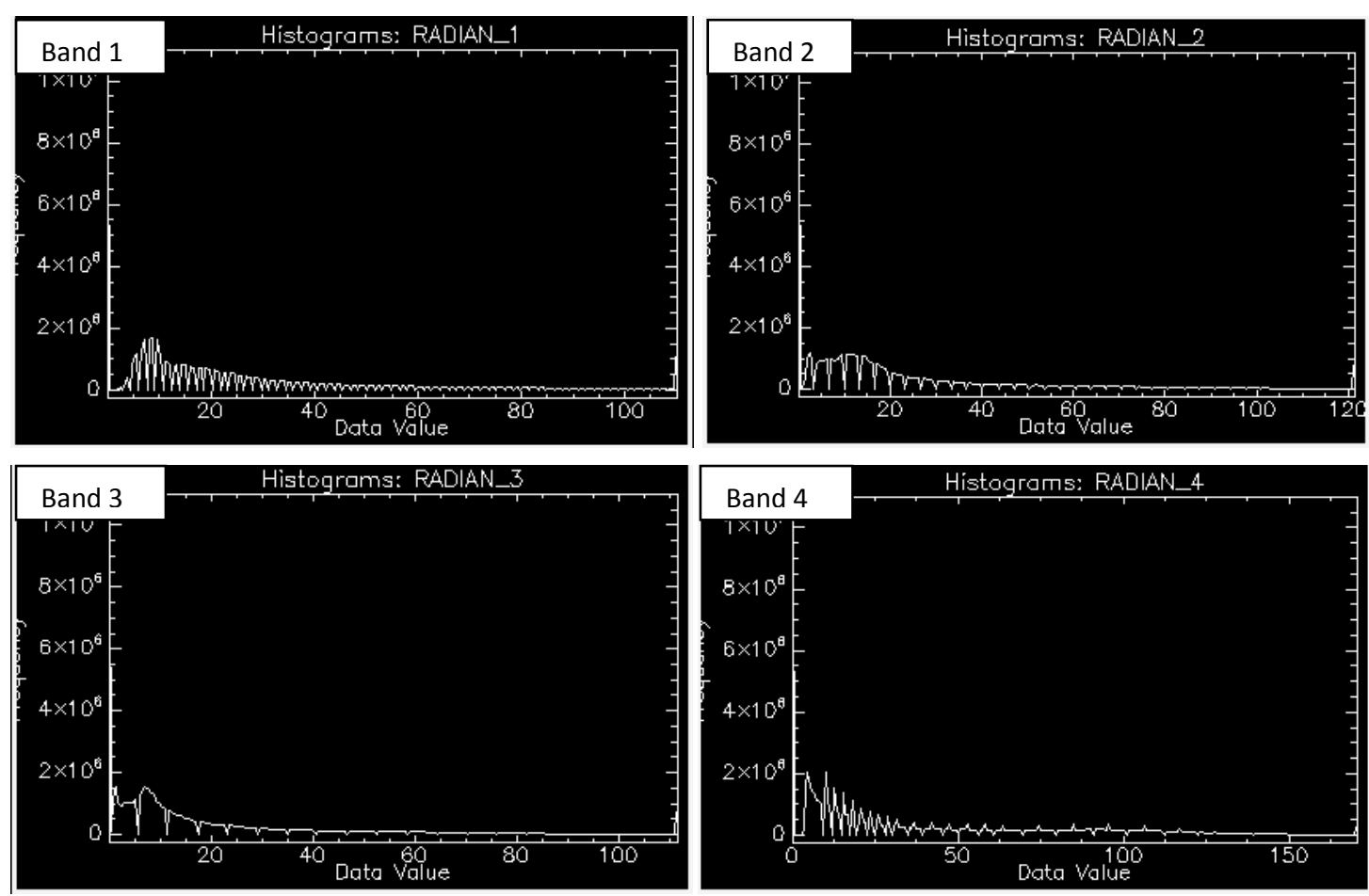

Gambar 3. Histogram Nilai Radiansi Spectral Citra ALOS AVNIR-2 Area Penelitian (Radiansi Specktral Citra Band 1, Band 2, Band 3 dan Band 4)

Tabel 6. Nilai Digital Radiansi Citra ALOS AVNIR-2 Masing-masing Band

\begin{tabular}{|c|c|c|}
\hline No & $\begin{array}{c}\text { Band } \\
(\mu \mathrm{m})\end{array}$ & \multicolumn{1}{c|}{$\begin{array}{c}\text { Nilai Digital Radiansi } \\
\left(\mathrm{Wm}^{-2} \mathrm{sr}^{-1} \mu^{-1}\right)\end{array}$} \\
\hline 1 & $0.42-0.50$ & $0-110$ \\
\hline 2 & $0.52-0.60$ & $0-121$ \\
\hline 3 & $0.61-0.69$ & $0-111$ \\
\hline 4 & $0.76-0.89$ & $0-170$ \\
\hline
\end{tabular}

\section{Kesimpulan dan Saran}

Kesimpulan yang dapat diperoleh dari hasil penelitian yaitu nilai radiansi pada citra ALOS AVNIR-2 di wilayah Sidangoli Dehe diperoleh band 11 dengan nilai $0-110 \mathrm{wm}^{-2} \mathrm{sr}^{-1}$ $\mu \mathrm{m}^{-1}$, band 2 dengan nilai $0-121 \mathrm{wm}^{-2} \mathrm{sr}^{-1} \mu \mathrm{m}^{-1}$, band 3 dengan nilai $0-111 \mathrm{wm}^{-2} \mathrm{sr}^{-1} \mu \mathrm{m}^{-1}$, dan band 4 dengan nilai $0-170 \mathrm{wm}^{-2} \mathrm{sr}^{-1} \mu \mathrm{m}^{-1}$.

Saran yang dapat direkomendasikan dari hasil penelitian ini adalah perlu dilakukan penelitian uji banding nilai radiansi terhadap jenis citra satelit dari lain dengan resolusi yang berbeda pada wilayah penelitian yang sama. 


\section{Daftar Pustaka}

Butler, M.J. A., Mochot, M. C., Berack, V., and LeBlanc, C. 1988. The Aplication of Remote Technology to Marine Fisheries. An Introduction Manual. FAO. Fisheries Technical Paper.

JAXA. 2008. ALOS data users handbook : revision C. Earth Observation Research and Application Center. Tokyo. Jepang.

Lillesand, T.M; and R.W. Kiefer. 1997. Penginderaan Jauh dan Interpretasi Citra (Alih Bahasa: Dulbahri, dkk). Gajah Mada University Press. Yogyakarta.

Mather, P.M., 2004, Computer Processing of Remotely-Sensed Images, An Introduction, $3^{\text {rd }}$ ed., John Wiley \& Sons Ltd., West Sussex.

Sutanto. 1986. Penginderaan Jauh, Jilid I dan II. Gadjah Mada University Press. Yogyakarta. 